\title{
Cembrane-Type Diterpenoids and a Phenolic Compound from the Leaves of a Thai Medicinal Plant, Croton sublyratus Kurz
}

\author{
Yasue Oka1, Susumu Kawakami', Sachiko Sugimoto'1, Katsuyoshi Matsunami1, \\ Hideaki Otsuka ${ }^{1,2 *}$, Duanporn Lhieochaiphant ${ }^{3}$, Sorasak Lhieochaiphant ${ }^{4}$ \\ ${ }^{1}$ Department of Pharmacognosy, Graduate School of Biomedical and Health Sciences, Hiroshima \\ University, Hiroshima, Japan \\ ${ }^{2}$ Departmernt of Natural Products Chemistry, Faculty of Pharmacy, Yasuda Women's University, \\ Hiroshima, Japan \\ ${ }^{3}$ Department of Pharmaceutical Sciences, Faculty of Pharmacy, Chiang Mai University, Chiang Mai, \\ Thailand \\ ${ }^{4}$ Faculty of Pharmacy, Payap University, Chiang Mai, Thailand \\ Email: hotsuka@hiroshima-ac.jp, otsuka-h@yasuda-u.ac.jp
}

Received 19 February 2014; revised 28 March 2014; accepted 14 April 2014

Copyright (C) 2014 by authors and Scientific Research Publishing Inc.

This work is licensed under the Creative Commons Attribution International License (CC BY).

http://creativecommons.org/licenses/by/4.0/

\section{(c) (i) Open Access}

\section{Abstract}

From the leaves of a Thai medicinal plant, Croton sublyratus, collected in Thailand, two new cembrane-type diterpenoids, named sublylactones $A$ and $B$, and a phenolic compound were isolated from the EtOAc-soluble fraction of a MeOH extract. Their structures were elucidated on the basis of spectroscopic evidence.

\section{Keywords}

Croton Sublyratus; Euphorbiaceae; Diterpene; Cembrane

\section{Introduction}

Croton sublyratus, belonging to the Euphorbiaceae family, is called "Plau-Noi" in Thai. An acyclic diterpene alcohol, plaunotol, was isolated from this plant [1], which is already on the market as an anti-ulcerative agent called Kelnac [2]. Diterpenelactones, plaunols A and B [3] [4], and ent-labdane and ent-kaurane [5] have also 
been isolated from C. sublyratus. From this plant, isolation of a furanoid diterpene was also reported [6] [7]. Our reinvestigation of constituents of $C$. sublyratus resulted in the isolation of two cembrane-type diterpenoids, named sublylactones A (1) and B (2), and a phenolic compound (3) together with a known cembrane-type diterpenoid, laevigatlactone $\mathrm{E}$ (4), which has also been isolated from Croton laevigatus [8].

\section{Results and Discussion}

From the EtOAc-soluble fraction of a $\mathrm{MeOH}$ extract, two new cembrane-type diterpenes (1 and $\mathbf{2}$ ) and a phenolic compound (3) (Figure 1) were isolated by a combination of various types of chromatography. Their structures were elucidated from spectroscopic evidence.

Sublylactone A (1), $[\alpha]_{\mathrm{D}}^{23}+3.90$, was isolated as an amorphous powder and its elemental composition was determined to be $\mathrm{C}_{20} \mathrm{H}_{30} \mathrm{O}_{4}$ by the observation of a quasi-molecular ion $\left(\mathrm{C}_{20} \mathrm{H}_{30} \mathrm{O}_{4} \mathrm{Na}\right)$ on high-resolution (HR)electrospray ionization (ESI)-mass spectroscopy (MS). The IR spectrum exhibited absorption bands for hydroxyl groups $\left(3423 \mathrm{~cm}^{-1}\right)$, C-H $\left(2968,2929\right.$ and $\left.2881 \mathrm{~cm}^{-1}\right)$, a lactone $\left(1697 \mathrm{~cm}^{-1}\right)$, and double bonds $\left(1631 \mathrm{~cm}^{-1}\right)$, and the UV spectrum indicated the presence of a conjugated system $(234 \mathrm{~nm})$. In the ${ }^{1} \mathrm{H}-\mathrm{NMR}$ spectrum, signals assignable to two singlet methyls, two doublet methyls and five olefinic protons were observed (Table 1). The ${ }^{13} \mathrm{C}$-NMR spectrum showed twenty signals that were assignable to four methyls, five methylenes, one methine, three oxygenated tertiary carbons, three double bonds and a carbonyl carbon (Table 2). Of the three double bonds, two were disubstituted ones and their geometry was determined to be $E$ from the coupling constants of olefinic protons on them. ${ }^{1} \mathrm{H}-{ }^{1} \mathrm{H}$ correlation spectroscopy (COSY) established five partial structures, A: H-2 H-3, B: H-5 - H-7, C: H-9 - H-11, D: $\mathrm{H}_{2}-13-\mathrm{H}_{2}-14$ and E: $\mathrm{H}_{3}-16-\mathrm{H}-15-\mathrm{H}_{3}-17$, and these partial structures were connected by heteronuclear multiple-bond correlation spectroscopy (HMBC) (Figure 2). Partial structures $\mathrm{A}$ and $\mathrm{B}$ were connected through an oxygenated tertiary carbon at $\delta_{\mathrm{C}} 72.5$ (C-4) by the following HMBC correlations: $\mathrm{H}_{3}-18$ to $\mathrm{C}-3, \mathrm{C}-4$ and $\mathrm{C}-5$, partial structures $\mathrm{B}$ and $\mathrm{C}$ through an oxygenated tertiary carbon at $\delta_{\mathrm{C}} 72.9$ (C-8) by the correlations: $\mathrm{H}_{3}-19$ to C-7, C-8 and C-9, and partial structures $\mathrm{C}$ and D through C-12 including the position of the carbonyl group by the following correlations: $\mathrm{H}-11$ to $\mathrm{C}-20, \mathrm{H}-13\left(\delta_{\mathrm{H}} 2.40\right)$ to $\mathrm{C}-20, \mathrm{H}_{2}-10$ to $\mathrm{C}-12$, and $\mathrm{H}_{2}-14$ to $\mathrm{C}-12$. Finally, partial structures $\mathrm{A}$ and $\mathrm{D}$ were connected through the remaining oxygenated tertiary carbon at $\delta_{\mathrm{C}} 87.4$ by the following correlations: $\mathrm{H}-2$ to $\mathrm{C}-1$ and $\mathrm{H}_{2}-14$ to $\mathrm{C}-1$. The dimethyl group (partial structure E) was placed on C- 1 by the HMBC correlations from $\mathrm{H}_{3}-16$ and $\mathrm{H}_{3}-17$ to C-1. Thus, a cyclic structure was proposed for sublylactone A (1), and the remaining one degree of unsaturation was expected to be compensated for by the formation of a lactone ring between the C-20 carboxylic acid and the hydroxy group at the C-1 position. Structurally related lactone cembranoids were isolated from Croton laevigatus as laevigatlac tones A-E and the relative structure of laevigatlactone A was determined by X-ray crystallographic analysis [8]. From the above evidence, the structure of sublylactone A (1) was expected to be that of a stereomeric isomer of laevigatlactone $\mathrm{E}(4)$, which was simultaneously isolated from this plant. On comparison of ${ }^{13} \mathrm{C}-\mathrm{NMR}$ spectral data for sublylactone A (1) and laevigatlactone E (4) (Table 2), C-2 to C-7 showed some differences, C-2 by 2.1 ppm, C-4 by $1.6 \mathrm{ppm}, \mathrm{C}-6$ by 0.7 and C-7 by $0.7 \mathrm{ppm}$. The most prominent difference was observed between the C-18 methyls, 6.2 ppm (Table 2). Therefore, the structure of sublylactone A (1) was elucidated to be 4-epi-laevigatlactone E, as shown in Figure 1.

Sublylactone B (2), $[\mathrm{M}]_{\mathrm{D}}-1.45$, was isolated as an amorphous powder and its elemental composition was the same as that of $\mathbf{1}$, NMR spectroscopic data also indicating that $\mathbf{2}$ possessed the same functionality as that of $\mathbf{1}$. The geometry of two disubstituted double bonds ( $C-2=C-3$ and $C-6=C-7)$ was assigned as $E$ from the coupling constants of their olefinic protons. The remaining double bond $(\mathrm{C}-11=\mathrm{C}-12)$ was assigned to $Z$ geometry from the significant evidence of the NOE correlation between the olefinic proton at $\mathrm{H}-11\left(\mathrm{M}_{\mathrm{H}} 5.91\right)$ and $\mathrm{H}_{2}-13\left(\delta_{\mathrm{H}}\right.$ 2.48) in the phase-sensitive NOESY spectrum (Figure 3). The relative structures of the methyl groups at the 4and 8-positions were estimated to be in a $\beta$ orientation from the NOE correlation peaks between $\mathrm{H}_{3}-18$ and $\mathrm{H}-7$, $\mathrm{H}_{3}-19$ and $\mathrm{H}-7$, and $\mathrm{H}_{3}-19$ and $\mathrm{H}-10\left(\delta_{\mathrm{H}} 3.47\right)$ (Figure 3). Therefore, the relative structure was elucidated to be as shown in Figure 1.

Phenolic compound (3), $[\alpha]_{\mathrm{D}}{ }^{25}-0.47$, was isolated as an amorphous powder and its elemental composition was determined to be $\mathrm{C}_{19} \mathrm{H}_{22} \mathrm{O}_{6}$ by positive-ion HR-ESI-MS. The IR spectrum exhibited distinct absorptions assignable to hydroxy groups $\left(3445 \mathrm{~cm}^{-1}\right)$ and an ester functional group $\left(1701 \mathrm{~cm}^{-1}\right)$. The ${ }^{1} \mathrm{H}$ NMR together with the ${ }^{13} \mathrm{C}$ spectral data suggested the presence of monosubstituted and symmetrically tetrasubstituted aromatic rings as well as one methoxy signal $\left(\delta_{\mathrm{H}} 3.87\right)$ for six protons, and one methoxy signal $\left(\delta_{\mathrm{H}} 3.23\right)$ for three protons 

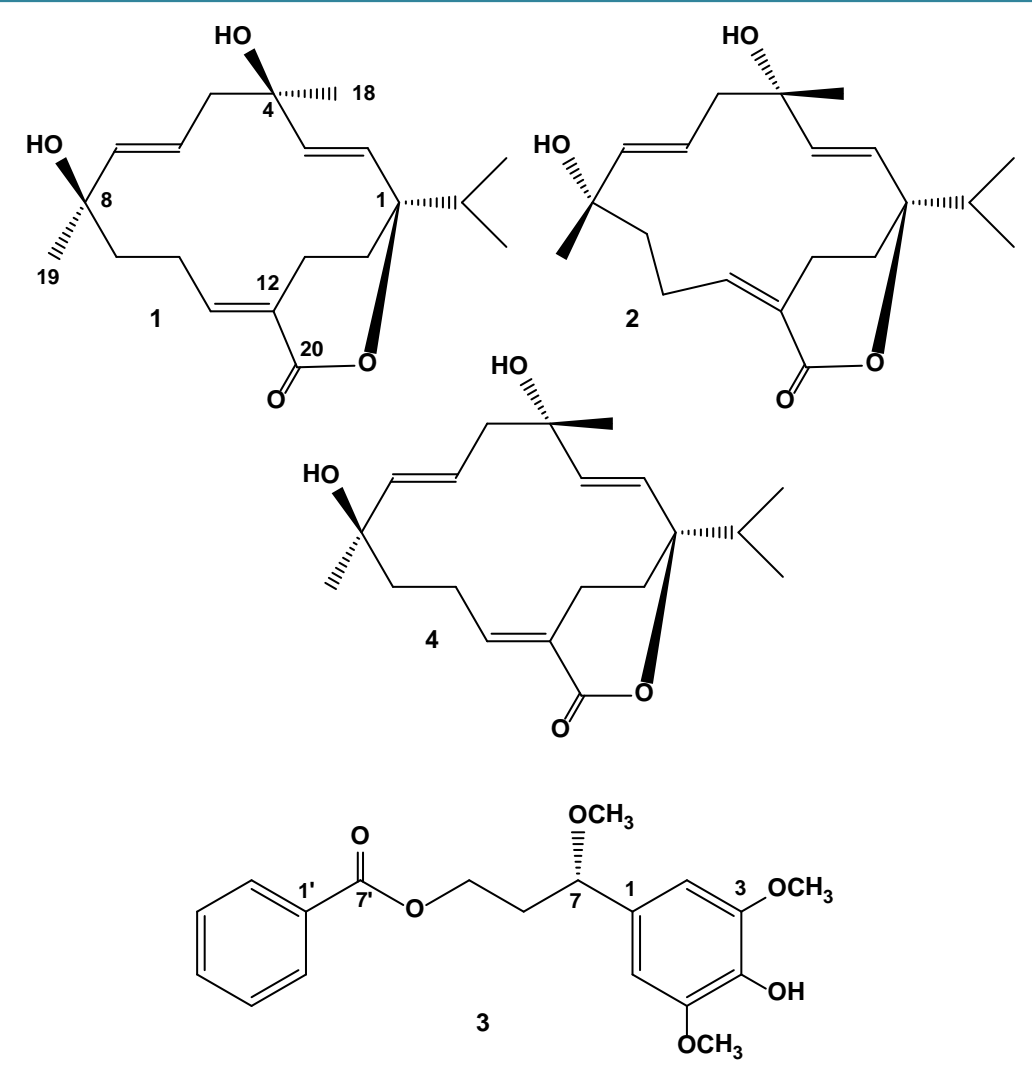<smiles>COc1cc([C@H](CCO)OC)cc(OC)c1O</smiles>

Figure 1. Structures of compounds isolated.

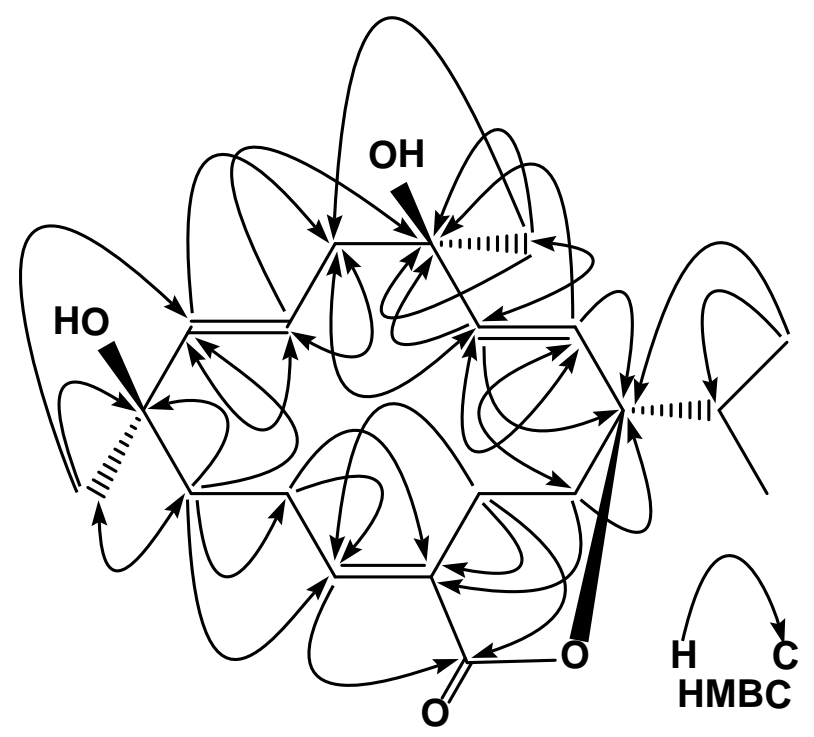

Figure 2. HMBC correlations of 1. 
Table 1. ${ }^{1} \mathrm{H}-\mathrm{NMR}$ spectral data for sublylactones A (1) and B (2), and $4\left(\mathrm{CDCl}_{3}, 600 \mathrm{MHz}\right)$.

\begin{tabular}{ccccc}
\hline $\mathrm{H}$ & & 1 & 2 & 3 \\
\hline 2 & $5.41(\mathrm{~d}, 16)$ & {$[5.48](\mathrm{d}, 16)$} & $5.60(\mathrm{~d}, 16)$ & {$[5.54](\mathrm{d}, 16)$} \\
3 & $5.45(\mathrm{~d}, 16)$ & {$[5.36](\mathrm{d}, 16)$} & $5.48(\mathrm{~d}, 16)$ & {$[5.23](\mathrm{d}, 16)$} \\
5 & $2.34(2 \mathrm{H}, \mathrm{d}, 7)$ & {$[2.31](2 \mathrm{H}, \mathrm{m})$} & $2.09(\mathrm{dd}, 13,12)$ & {$[2.18](\mathrm{m})$} \\
& & & $2.45(\mathrm{ddd}, 13,2,2)$ & {$[2.32](\mathrm{ddd}, 15,3,3)$} \\
6 & $5.45(\mathrm{~d}, 16)$ & {$[5.38](\mathrm{br} \mathrm{d}, 16)$} & $5.63(\mathrm{ddd}, 15,12,3)$ & {$[5.64](\mathrm{ddd}, 16,11,3)$} \\
7 & $5.49(\mathrm{~d}, 16)$ & {$[5.41](\mathrm{dd}, 16,2)$} & $5.35(\mathrm{dd}, 15,2)$ & {$[5.34](\mathrm{dd}, 16,2)$} \\
9 & $1.87(\mathrm{~m})$ & {$[1.84](2 \mathrm{H}, \mathrm{m})$} & $1.66(\mathrm{dd}, 14,14)$ & {$[1.85(2 \mathrm{H}, \mathrm{m})$} \\
& $1.90(\mathrm{~m})$ & & $1.89(\mathrm{~m})$ & {$[2.15(\mathrm{dd}, 12,3)$} \\
10 & $2.16(2 \mathrm{H}, \mathrm{m})$ & {$[2.18](2 \mathrm{H}, \mathrm{m})$} & $2.20(\mathrm{~m})$ & {$[2.24](\mathrm{m})$} \\
& & & $3.47(\mathrm{~m})$ & {$[2.24](\mathrm{m})$} \\
11 & $6.95(\mathrm{~m})$ & {$[6.89](\mathrm{ddd}, 11,2,2)$} & $2.48(2 \mathrm{H}, \mathrm{m})$ & {$[2.44](\mathrm{ddd}, 17,6,5,2)$} \\
13 & $2.35(2 \mathrm{H}, \mathrm{dd}, 14,6)$ & {$[2.22](\mathrm{m})$} & & {$[1.75](\mathrm{ddd}, 14,14,6)$} \\
& & {$[2.40](\mathrm{ddd}, 17,2,2)$} & $1.79(\mathrm{~m})$ & {$[1.84](\mathrm{m})$} \\
14 & $1.79(\mathrm{ddd}, 14,14,6)$ & {$[1.76](\mathrm{ddd}, 14,14,6)$} & $1.88(\mathrm{~m})$ & {$[0.97](3 \mathrm{H}, \mathrm{d}, 7)$} \\
15 & $1.95(\mathrm{dd}, 14,6)$ & {$[2.04](\mathrm{dd}, 14,6)$} & $1.84(\mathrm{~m})$ & {$[0.97](3 \mathrm{H}, \mathrm{d}, 7)$} \\
16 & $1.88(\mathrm{~m})$ & {$[1.86](\mathrm{m})$} & $0.95(3 \mathrm{H}, \mathrm{d}, 7)$ & {$[1.28](3 \mathrm{H}, \mathrm{s})$} \\
18 & $0.98(3 \mathrm{H}, \mathrm{d}, 7)$ & {$[0.98](3 \mathrm{H}, \mathrm{d}, 7)$} & $0.96(3 \mathrm{H}, \mathrm{d}, 7)$ & {$[1.31](3 \mathrm{H}, \mathrm{s})$} \\
\hline
\end{tabular}

Data in brackets are for $\mathrm{CD}_{3} \mathrm{OD}$. In parentheses, number of hydrogen are specified, when they are not $1 \mathrm{H}$. Letters and figures are multiplicities and $J$ in $\mathrm{Hz}$ ).

Table $2 .{ }^{13} \mathrm{C}-\mathrm{NMR}$ spectral data for sublylac- tones A (1) and B (2), and laevigatlactone E (4) $\left(\mathrm{CDCl}_{3}, 150 \mathrm{MHz}\right)$.

\begin{tabular}{|c|c|c|c|c|c|}
\hline $\mathrm{C}$ & 1 & & 2 & 4 & \\
\hline 1 & 85.5 & $(87.4)$ & 86.7 & 85.7 & $(87.7)$ \\
\hline 2 & 127.2 & (128.4) & 124.6 & 125.2 & (126.3) \\
\hline 3 & 138.5 & $(140.0)$ & 139.1 & 138.8 & (140.3) \\
\hline 4 & 72.5 & $(73.0)$ & 73.6 & 73.7 & $(74.1)$ \\
\hline 5 & 46.6 & $(48.4)$ & 49.1 & 46.2 & $(47.6)$ \\
\hline 6 & 123.9 & (125.0) & 122.8 & 124.3 & (125.7) \\
\hline 7 & 138.0 & (139.1) & 140.4 & 137.7 & (138.4) \\
\hline 8 & 72.4 & (72.9) & 72.0 & 72.4 & $(73.0)$ \\
\hline 9 & 41.0 & $(42.4)$ & 42.2 & 41.4 & $(42.5)$ \\
\hline 10 & 25.6 & (25.9) & 25.1 & 25.0 & (25.9) \\
\hline 11 & 145.9 & (148.5) & 150.4 & 146.1 & (148.4) \\
\hline 12 & 124.3 & (125.5) & 123.2 & 124.4 & (125.6) \\
\hline 13 & 21.0 & (21.9) & 24.9 & 21.1 & $(22.0)$ \\
\hline 14 & 26.8 & $(28.2)$ & 28.2 & 27.8 & (28.9) \\
\hline 15 & 37.1 & (38.3) & 36.9 & 37.0 & (38.1) \\
\hline 16 & 17.2 & $(17.7)$ & 17.3 & 17.4 & (17.7) \\
\hline 17 & 16.8 & (16.9) & 16.6 & 16.5 & (16.8) \\
\hline 18 & 25.1 & $(24.7)$ & 28.3 & 31.1 & (30.9) \\
\hline 19 & 26.5 & (25.8) & 31.4 & 24.7 & (24.7) \\
\hline 20 & 167.7 & (170.6) & 167.4 & 169.0 & (170.7) \\
\hline
\end{tabular}

Data in parentheses are for $\mathrm{CD}_{3} \mathrm{OD}$. 


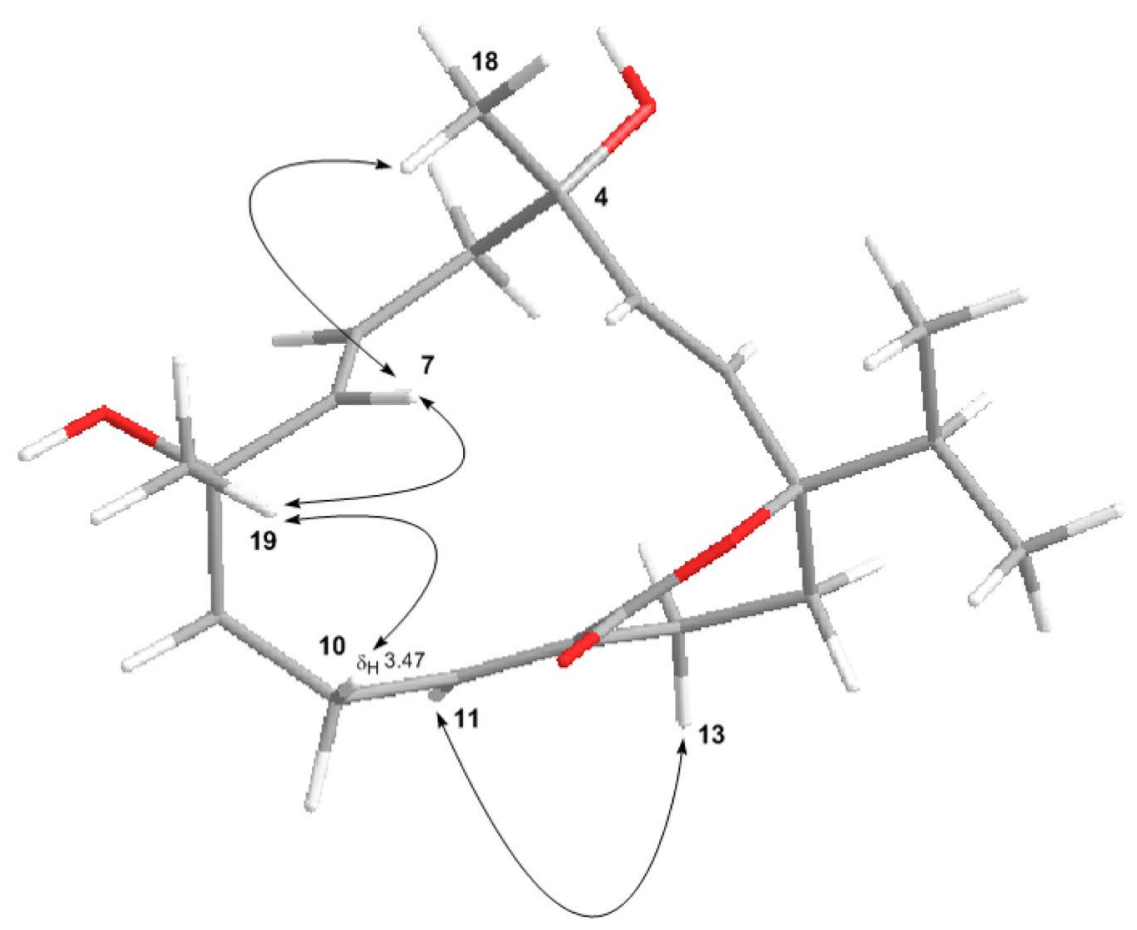

Figure 3. NOESY correlations of 1.

(Table 3). From their chemical shifts, the former were expected to be on the aromatic carbons and the latter on the aliphatic carbon. The remaining signals comprised those of one methylene, one oxygenated methylene, one oxygenated methine and a carbonyl carbon. In the ${ }^{1} \mathrm{H}-{ }^{1} \mathrm{H}$ COSY spectrum, two proton chains were observed, these are oxymethylene $\left(\mathrm{H}_{2}-9\right)$-methylene $\left(\mathrm{H}_{2}-8\right)$-oxymethine $(\mathrm{H}-7)$ and $\mathrm{H}-2$ ' through $\mathrm{H}-4$ '. In the HMBC spectrum, oxymethylene protons $\left(\delta_{\mathrm{H}} 4.36\right.$ and 4.41$)$ showed significant correlation cross peaks with the carbonyl carbon $\left(\delta_{\mathrm{C}} 166.5\right)$, to which the aromatic protons of H-2' and 6' $\left[\delta_{\mathrm{H}} 8.02(2 \mathrm{H}, \mathrm{dd}, J=8,1 \mathrm{~Hz})\right]$ were also correlated. The oxymethylene protons further correlated with C-7 ( $\left.\delta_{\mathrm{C}} 81.2\right)$ and methylene protons $\left(\delta_{\mathrm{H}} 2.08\right.$ and 2.25$)$ with C-1 $\left(\delta_{\mathrm{C}} 132.9\right)$. The positions of the methoxy groups were assigned as on C-3 and 5, and C-7 by the HMBC correlation shown in Figure 4. Therefore, the structure of $\mathbf{3}$ was elucidated to be 7-methoxydihydrosynapyl alcohol 9-O-benzoyl ester, as shown in Figure 1. Due to the very small optical rotation value, it is uncertain whether 3 is a racemic, partially racemic or chiral compound. A related compound, (7S)-7-methoxydihydrosynapyl alcohol (5) was isolated from Acer truncatum [9]. The optical rotation value of $\mathbf{5}$ was reported to be -6.8 in $\mathrm{CHCl}_{3}\left([\mathrm{M}]_{\mathrm{D}}-16.4\right.$, where molecular rotation is calculated as $\left.[\mathrm{M}]_{\mathrm{D}}=[\alpha]_{\mathrm{D}} \times \mathrm{MW} . / 100\right)$. Thus, $3\left([\mathrm{M}]_{\mathrm{D}}\right.$ -5.0 ) was estimated to be nearly a racemic compound in which an $S$-form is slightly dominant.

\section{Material and Method}

\subsection{Plant Material}

Leaves of C. sublyratus were collected in the Botanical Garden of the Faculty of Pharmacy, Chiang Mai University, Thailand in July 2008. A voucher specimen was deposited in the Herbarium of the Faculty of Pharmacy, Chiang Mai University (CS-CMU-July-2008).

\subsection{General Experimental Proceddures}

Optical rotations were measured on a JASCO P-1030 digital polarimeter. IR and UV spectra were measured on Horiba FT-710 and JASCO V-520 UV/Vis spectrophotometers, respectively. ${ }^{1} \mathrm{H}$ - and ${ }^{13} \mathrm{C}-\mathrm{NMR}$ spectra were taken on a JEOL ECA-600 at $600 \mathrm{MHz}$ and $150 \mathrm{MHz}$ with tetramethylsilane as an internal standard. Positiveion HR-ESI-MS was performed with an Applied Biosystems QSTAR XL NanoSprayTM System. Silica gel CC was performed on silica gel 60 (E. Merck, Darmstadt, Germany). 
Table 3. NMR spectroscopic data for compound 1 (3) $\left(\mathrm{CDCl}_{3},{ }^{13} \mathrm{C}: 100 \mathrm{MHz},{ }^{1} \mathrm{H}: 400 \mathrm{MHz}\right)$.

\begin{tabular}{|c|c|c|}
\hline & $\mathrm{C}$ & $\mathrm{H}$ \\
\hline 1 & 132.9 & - \\
\hline 2,6 & 103.3 & $6.55(2 \mathrm{H}, \mathrm{s})$ \\
\hline 3,5 & 147.3 & - \\
\hline 4 & 134.3 & - \\
\hline 7 & 81.2 & $4.22(1 \mathrm{H}, \mathrm{dd}, 8,6)$ \\
\hline \multirow[t]{2}{*}{8} & 37.4 & $2.08(1 \mathrm{H}, \mathrm{m})$ \\
\hline & & $2.25(1 \mathrm{H}, \mathrm{m})$ \\
\hline \multirow[t]{2}{*}{9} & 62.4 & \\
\hline & & $4.41(1 \mathrm{H}, \mathrm{m})$ \\
\hline $1^{\prime}$ & 130.4 & - \\
\hline $2^{\prime}, 6^{\prime}$ & 129.5 & $8.02(2 \mathrm{H}, \mathrm{dd}, 8,1)$ \\
\hline $3^{\prime}, 5$ & 128.4 & $7.44(2 \mathrm{H}, \mathrm{dd}, 8,8)$ \\
\hline $4^{\prime}$ & 132.9 & $7.56(1 \mathrm{H}, \mathrm{tt}, 8,1)$ \\
\hline $7^{\prime}$ & 166.5 & - \\
\hline 4'-OH & & $5.49(1 \mathrm{H}, \mathrm{s})$ \\
\hline 3, 5-OMe & 56.4 & $3.87(6 \mathrm{H}, \mathrm{s})$ \\
\hline $7 \mathrm{Me}$ & 56.6 & $3.23(3 \mathrm{H}, \mathrm{s})$ \\
\hline
\end{tabular}

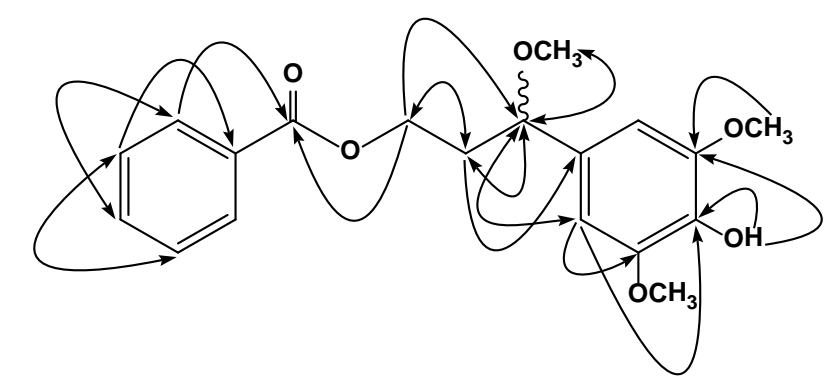

Figure 4. HMBC correlations of compound 1 (3).

\subsection{Extraction and Isolation}

Powdered and air-dried leaves of $C$. sublyratus (450 g) were extracted with $\mathrm{MeOH}(2 \mathrm{~L} \times 3)$ and the total extracts were concentrated to $1 \mathrm{~L}$. The concentrated $\mathrm{MeOH}$ extract was washed with $n$-hexane $(1 \mathrm{~L}, 7.35 \mathrm{~g})$ and then the remaining $\mathrm{MeOH}$ layer was concentrated to a viscous gum. The viscous gum was suspended in $\mathrm{H}_{2} \mathrm{O}(1$ $\mathrm{L})$, and then partitioned successively with EtOAc $(1 \mathrm{~L})$ and 1-BuOH $(1 \mathrm{~L})$ to give EtOAc-soluble $(24.0 \mathrm{~g})$ and 1-BuOH-soluble (7.88 g) fractions, respectively. The $\mathrm{H}_{2} \mathrm{O}$ layer was evaporated to leave $16.3 \mathrm{~g}$ of a residue.

The residue (24.0 g) of the EtOAc-soluble fraction was subjected to silica gel (500 g) CC with a solvent system consisting of $n$-hexane (3 L), $n$-hexane-EtOAc [9:1 (3 L), 4:1 (3 L), 7:3 (3 L), 3:2 (3 L), 1:1 (3 L), and 3:7 (3 L)], EtOAc (3 L), and MeOH (3 L), $1 \mathrm{~L}$ fractions being collected. The residue (3.51 g) in fractions 6 - 8 was fractionated by ODS CC (Cosmosil $\left.75 \mathrm{C}_{18} \mathrm{OPN}\right)(\Phi=40 \mathrm{~mm}, L=250 \mathrm{~mm})$, by elution with $\mathrm{H}_{2} \mathrm{O}-\mathrm{MeOH}[(3: 7$, $800 \mathrm{~mL}),(1: 3,800 \mathrm{~mL}),(1: 4,800 \mathrm{~mL}),(3: 17,800 \mathrm{~mL}),(1: 9,800 \mathrm{~mL})$, and (1:19, $800 \mathrm{~mL})], \mathrm{MeOH}(800 \mathrm{~mL})$, $\left(\mathrm{CH}_{3}\right)_{2} \mathrm{CO}(800 \mathrm{~mL})$, and EtOAc $(800 \mathrm{~mL}), 800 \mathrm{~mL}$ fractions being collected. The residue $(745 \mathrm{mg})$ in fraction 1 was further separated by ODS CC (Cosmosil $\left.75 \mathrm{C}_{18} \mathrm{OPN}\right)(\Phi=40 \mathrm{~mm}, L=250 \mathrm{~mm})$ using $\mathrm{H}_{2} \mathrm{O}-\mathrm{MeOH}[(7: 3$, $800 \mathrm{~mL}),(3: 2,800 \mathrm{~mL}),(1: 1,800 \mathrm{~mL}),(2: 3,800 \mathrm{~mL}),(7: 13,800 \mathrm{~mL})$, and $(3: 7.800 \mathrm{~mL})]$, and $\mathrm{MeOH}(800$ $\mathrm{mL}), 800 \mathrm{~mL}$-fractions being collected. The residue $(108 \mathrm{mg})$ in fraction 4 was again purified by silica gel CC ( $\Phi=10 \mathrm{~mm}, L=30 \mathrm{~cm}$ ) with a linear gradient solvent system from $n$-hexane $(250 \mathrm{~mL})$ to $n$-hexane-EtOAc $(1: 1$, $250 \mathrm{~mL}$ ), 4-gram fractions being collected. From fractions 109-120, $5.6 \mathrm{mg}$ of 2 was obtained.

The residue (869 mg) in fractions 11 - 12 obtained on the first silica gel CC was separated by ODS CC with $\mathrm{H}_{2} \mathrm{O}-\mathrm{MeOH}$ [(7:3, $\left.800 \mathrm{~mL}\right),(3: 2,800 \mathrm{~mL}),(1: 1,800 \mathrm{~mL}),(2: 3,800 \mathrm{~mL}),(7: 13,800 \mathrm{~mL}),(3: 7.800 \mathrm{~mL}),(1: 3$, $800 \mathrm{~mL}),(1: 4,800 \mathrm{~mL}),(3: 17,800 \mathrm{~mL}),(1: 9,800 \mathrm{~mL})$, and $(1: 19,800 \mathrm{~mL})], \mathrm{MeOH}(800 \mathrm{~mL}),\left(\mathrm{CH}_{3}\right)_{2} \mathrm{CO}(800$ 
$\mathrm{mL})$, and EtOAc $(800 \mathrm{~mL}), 800 \mathrm{~mL}$ fractions being collected. The residue $(203 \mathrm{mg})$ in fraction 3 was purified by silica gel CC $(\Phi=10 \mathrm{~mm}, L=40 \mathrm{~cm})$ with a linear gradient solvent system from $n$-hexane $(250 \mathrm{~mL})$ to $n$-hexane-EtOAc (1:1, $250 \mathrm{~mL})$, 4-gram fractions being collected. Further amounts of $n$-hexane-EtOAc (1:1, 750 $\mathrm{mL})$ and $\mathrm{MeOH}(250 \mathrm{~mL})$ were eluted and $250 \mathrm{~mL}$-fractions were collected. From the third $n$-hexane-EtOAc (1:1, $250 \mathrm{~mL})$ fraction, $11.0 \mathrm{mg}$ of 4 was obtained. The residue $(276 \mathrm{mg})$ in fraction 4 was separated by silica gel CC ( $\Phi=10 \mathrm{~mm}, L=40 \mathrm{~cm}$ ) with a linear gradient solvent system from $n$-hexane ( $250 \mathrm{~mL})$ to $n$-hexaneEtOAc (1:1, $250 \mathrm{~mL})$, 4-gram fractions being collected. From fractions 67 - 74, $20.0 \mathrm{mg}$ of 3 was obtained.

The residue $(1.17 \mathrm{~g})$ in fractions 13 - 14 obtained on the first silica gel CC was separated by ODS CC with $\mathrm{H}_{2} \mathrm{O}-\mathrm{MeOH}$ [(7:3, $\left.800 \mathrm{~mL}\right),(3: 2,800 \mathrm{~mL}),(1: 1,800 \mathrm{~mL}),(2: 3,800 \mathrm{~mL}),(7: 13,800 \mathrm{~mL}),(3: 7.800 \mathrm{~mL}),(1: 3$, $800 \mathrm{~mL}),(1: 4,800 \mathrm{~mL}),(3: 17,800 \mathrm{~mL}),(1: 9,800 \mathrm{~mL})$, and (1:19, $800 \mathrm{~mL})], \mathrm{MeOH}(800 \mathrm{~mL}),\left(\mathrm{CH}_{3}\right)_{2} \mathrm{CO}(800$ $\mathrm{mL})$, and EtOAc $(800 \mathrm{~mL}), 800 \mathrm{~mL}$ fractions being collected. The residue $(121 \mathrm{mg})$ in fraction 3 was purified by silica gel CC $(\Phi=10 \mathrm{~mm}, L=34 \mathrm{~cm})$ with a linear gradient solvent system from $n$-hexane $(250 \mathrm{~mL})$ to $n$-hexane-EtOAc (1:1, $250 \mathrm{~mL})$, and $n$-hexane-EtOAc $(1: 1,700 \mathrm{~mL})$. Further amounts of $n$-hexane-EtOAc (1:1, $250 \mathrm{~mL})$ and $\mathrm{MeOH}(250 \mathrm{~mL})$ were eluted. From the final $250 \mathrm{~mL} n$-hexane-EtOAc fraction, $8.2 \mathrm{mg}$ of $\mathbf{1}$ was obtained.

The residue (779 $\mathrm{mg}$ ) in fractions 17 - 18 obtained on the first silica gel CC was separated by ODS CC with $\mathrm{H}_{2} \mathrm{O}-\mathrm{MeOH}$ [(7:3, $\left.800 \mathrm{~mL}\right),(3: 2,800 \mathrm{~mL}),(1: 1,800 \mathrm{~mL}),(2: 3,800 \mathrm{~mL}),(7: 13,800 \mathrm{~mL}),(3: 7.800 \mathrm{~mL}),(1: 3$, $800 \mathrm{~mL}),(1: 4,800 \mathrm{~mL}),(3: 17,800 \mathrm{~mL}),(1: 9,800 \mathrm{~mL})$, and (1:19, $800 \mathrm{~mL})], \mathrm{MeOH}(800 \mathrm{~mL}),\left(\mathrm{CH}_{3}\right)_{2} \mathrm{CO}(800$ $\mathrm{mL})$, and EtOAc $(800 \mathrm{~mL}), 800 \mathrm{~mL}$ fractions being collected. The residue $(74.2 \mathrm{mg})$ in fraction 3 was purified by silica gel CC $(\Phi=10 \mathrm{~mm}, L=28 \mathrm{~cm})$ with a linear gradient solvent system from $n$-hexane $(250 \mathrm{~mL})$ to $n$-hexane-EtOAc (1:1, $250 \mathrm{~mL})$, 4-gram fractions being collected. From fractions 101 - 124, a further amount of 2 (17.2 mg) was obtained.

\subsection{Sublylactone A (1)}

Amorphous powder, $[\alpha]_{\mathrm{D}}^{23}+3.90$ (c 0.28, $\mathrm{CHCl}_{3}$ ); IR $v_{\max }(\mathrm{film}) \mathrm{cm}^{-1}: 3423,2968,2929,2881,1697,1631$, 1469, 1371, 1320, 1267, 1094, 977; UV $\lambda_{\max }(\mathrm{MeOH}) \mathrm{nm}(\log \varepsilon): 234$ (3.56); ${ }^{1} \mathrm{H}-\mathrm{NMR}\left(\mathrm{CDCl}_{3}\right.$ and $\mathrm{CD}_{3} \mathrm{OD}, 600$ $\mathrm{MHz}$ ): Table 1; ${ }^{13} \mathrm{C}-\mathrm{NMR}\left(\mathrm{CDCl}_{3}\right.$ and $\mathrm{CD}_{3} \mathrm{OD}, 150 \mathrm{MHz}$ ): Table 2; HR-ESI-MS (positive-ion mode): 357.2036 $[\mathrm{M}+\mathrm{Na}]^{+}$(Calcd for $\mathrm{C}_{20} \mathrm{H}_{30} \mathrm{O}_{4} \mathrm{Na}$ : 357.2036).

\subsection{Sublylactone B (2)}

Amorphous powder, $[\alpha]_{\mathrm{D}}^{25}-1.45$ (c 0.46, $\mathrm{CD}_{3} \mathrm{OD}$ ); IR $v_{\max }$ (film) $\mathrm{cm}^{-1}$ : 3445, 2967, 2929, 2881, 1693, 1630, 1455, 1381, 1320, 1244, 1118, 978; UV $\lambda_{\max }(\mathrm{MeOH}) \mathrm{nm}(\log \varepsilon): 233$ (3.76); ${ }^{1} \mathrm{H}-\mathrm{NMR}\left(\mathrm{CDCl}_{3}, 600 \mathrm{MHz}\right)$ Table 1; ${ }^{13} \mathrm{C}-\mathrm{NMR}\left(\mathrm{CDCl}_{3}, 150 \mathrm{MHz}\right)$ : Table 1; HR-ESI-MS (positive-ion mode): 357.2031 [M + Na] ${ }^{+}$(Calcd for $\mathrm{C}_{20} \mathrm{H}_{30} \mathrm{O}_{4} \mathrm{Na}$ : 357.2036).

\subsection{Compound 1 (3)}

Amorphous powder, $[\alpha]_{\mathrm{D}}^{25}-0.47$ (c 0.54, $\mathrm{CHCl}_{3}$ ); IR $v_{\max }$ (film) $\mathrm{cm}^{-1}: 3445,2962,2934,2841,1701,1274$; UV $\lambda_{\max }(\mathrm{MeOH}) \mathrm{nm}(\log \varepsilon): 212$ (4.20), 227 (4.14); ${ }^{1} \mathrm{H}-\mathrm{NMR}\left(\mathrm{CDCl}_{3}, 600 \mathrm{MHz}\right)$ : Table 3; ${ }^{13} \mathrm{C}-\mathrm{NMR}\left(\mathrm{CDCl}_{3}, 150\right.$ MHz): Table 3; HR-ESI-MS (positive-ion mode): 369.1311 [M + Na] $]^{+}$(Calcd for $\mathrm{C}_{19} \mathrm{H}_{22} \mathrm{O}_{6} \mathrm{Na}$ : 369.1308).

\section{Acknowledgements}

The authors are grateful for access to the superconducting NMR instrument (JEOL JNM $\alpha-400)$ and an Applied Biosystem QSTAR XL system ESI (Nano Spray)-MS at the Analysis Center of Life Science of the Graduate School of Biomedical Sciences, Hiroshima University. This work was supported in part by Grants-in-Aid from the Ministry of Education, Culture, Sports, Science and Technology of Japan, and the Japan Society for the Promotion of Science. Thanks are also due to the Research Foundation for Pharmaceutical Sciences and the Takeda Science Foundation for the financial support.

\section{References}

[1] Kapchan, S.M., Komoda, Y., Court, W.A., Thomas, G.J., Smith, R.M., Karim, A., Gilmore, C.J., Haltiwagner, R.C. 
and Bryan, B.F. (1972) Maytansine, a Novel Antileukemic Ansa Macrolide from Maytenus ovate. Journal of American Chemical Society, 94, 1354-1956. http://dx.doi.org/10.1021/ja00759a054

[2] Cassady, J.M., Chan, K.K., Floss, H.G. and Leistner, E. (2004) Recent Developments in the Maytansinoid Antitumor Agents. Chemical and Pharmaceutical Bulletin, 52, 1-26. http://dx.doi.org/10.1248/cpb.52.1

[3] Koyama, Y., Sugimoto, S., Matsunami, K. and Otsuka, H. (2010) Microtropiosides A-F: ent-Labdane Diterpenoid Glucosides from the Leaves of Microtropis japonica (Celastraceae). Phytochemistry, 71, 67-681. http://dx.doi.org/10.1016/j.phytochem.2010.01.004

[4] Uemura, Y., Sugimoto, S., Matsunami, K., Otsuka, H., Takeda, Y., Kawahata, M. and Yamaguchi, K. (2013) Microtropins A-I: 6'-O-(2"S,3"R)-2"-Ethyl-2",3"-Dihydroxybutyrates of Aliphatic Alcohol $\beta$-D-Glucopyranosides from the Branches of Microtropis japonica. Phytochemistry, 87, 140-147. http://dx.doi.org/10.1016/j.phytochem.2012.11.007

[5] Sakushima, A., Coşkun, M. and Maoka, T. (1995) Hydroxy-Benzoic Acids from Boreava orientalis. Phytochemistry, 40, 257-261. http://dx.doi.org/10.1016/0031-9422(95)00059-G

[6] Asakawa, Y., Toyota, M. and Harrison, L. (1985) Isotachin A and Isotachin B, Two Sulphur-Containing Acrylates from the Liverwort Isotachis japonica. Phytochemistry, 24, 1505-1508. http://dx.doi.org/10.1016/S0031-9422(00)81055-9

[7] Balboul, B.A.A.A., Ahmed, A.A., Otsuka, H. and de Adams, A. (1996) 4-Hydroxyphenylpropan-7,8-Diols and Derivatives from Narvalina domingensis. Phytochemisty, 42, 1191-193. http://dx.doi.org/10.1016/0031-9422(96)00116-1 